University of Wollongong

Research Online

Faculty of Law, Humanities and the Arts Papers (Archive)

Faculty of Arts, Social Sciences \& Humanities

$1-1-2018$

Corporate social responsibility and workplace casualties in Bangladesh: an appraisal of Islamic principles as a potential solution

S M. Solaiman

University of Wollongong, sheikh@uow.edu.au

Follow this and additional works at: https://ro.uow.edu.au/lhapapers

Part of the Arts and Humanities Commons, and the Law Commons

Research Online is the open access institutional repository for the University of Wollongong. For further information contact the UOW Library: research-pubs@uow.edu.au 


\title{
Corporate social responsibility and workplace casualties in Bangladesh: an appraisal of Islamic principles as a potential solution
}

\author{
Abstract \\ Bangladesh is home to around 6,000 garment factories, which make the industry the second largest \\ apparel manufacturer in the world just behind China. The garment industry as a single sector adds the \\ highest amount of foreign currency 1 to the gross domestic products (GDP) of the country. 2 This sector \\ alone earned more than US\$24 billion out of the total export revenue of US\$30.17 billion of Bangladesh in \\ the fiscal year 2013-14.3 However, a Harvard conference lately reveals that India has surpassed \\ Bangladesh by occupying the second position in the aftermath of the recent fatalities in the garment \\ industry that appear to have affected customer loyalty, contributing to this downtum.4 The industry \\ employs an estimated four million people; about 90 per cent of these are women who come from \\ impoverished, uneducated and untrained backgrounds and who are often teenagers. 5 They have found \\ this work in a demographic scenario where 32 percent of youths in the potential labour force are either \\ unemployed or underemployed as revealed from the latest population census of the country, which took \\ place in 2011.6 Taking advantage of such an awful dearth of job opportunities, garment owners can do \\ almost anything they want to do. Hence, the workers are to work in an exploitative environment that \\ includes safety risk, low salaries, sexual harassment, and both physical and verbal abuse.7 Employers \\ ignore the safety requirements assumingly with a belief that the law is confined to the books and people \\ are willing to work regardless of safety hazards. As a result, the number of workplace deaths and injuries \\ continues to grow day by day with virtual impunity being granted to the wrongdoers leaving no redress for \\ their victims. 8 The unprecedented fire at Tazreen Fashions Ltd in November 2012 and the horrific \\ collapse of Rana Plaza in April 2013 that claimed more than 1,000 lives and caused serious injuries to \\ many others have galvanised the agonies of garment workers in Bangladesh as discussed in Section IV \\ below. According to the US Committee on Foreign Relations, '[w] hen the Tazreen Fashions factory burned \\ down, it was the worst garment factory accident in Bangladesh's history. When Rana Plaza collapsed, it \\ was the worst garment factory accident in world history.' 9 The Committee adds that 'Bangladesh's \\ garment sector may not be able to withstand another tragedy on the scale of Tazreen and Rana Plaza' .10

\section{Disciplines} \\ Arts and Humanities | Law

\section{Publication Details} \\ S. M. Solaiman, 'Corporate social responsibility and workplace casualties in Bangladesh: an appraisal of \\ Islamic principles as a potential solution' in N. Hosen(ed), Research Handbook on Islamic Law and \\ Society (2018) 141-158.
}




\title{
Corporate Social Responsibility and Workplace Casualties in Bangladesh: An Appraisal of Islamic Principles as a Potential Solution
}

\author{
S M Solaiman
}

\section{Introduction}

Bangladesh is home to around six thousand garment factories, which make the industry the second largest apparel manufacturer in the world just behind China. The garment industry as a single sector adds the highest amount of foreign currency ${ }^{1}$ to the gross domestic products (GDP) of the country. ${ }^{2}$ This sector alone earned more than US\$24 billion out of the total export revenue of US\$30.17 billion of Bangladesh in the fiscal year 2013-2014. ${ }^{3}$ However, a Harvard conference lately reveals that India has surpassed Bangladesh by occupying the second position in the aftermath of the recent fatalities in the garment industry that appear to have affected customer loyalty, contributing to this downturn. ${ }^{4}$ The industry employs an estimated four million people, about 90 per cent of them are women coming from impoverished, uneducated and untrained backgrounds and are often teenagers. ${ }^{5}$ They have found this work in a demographic scenario where 32 percent of youths in the potential labour force are either unemployed or underemployed as revealed from the latest population census of the country, which took place in $2011 .^{6}$ Taking advantage of such an awful dearth of job opportunities, garment owners can do almost anything they want to do. Hence, the workers are to work in an exploitative environment that includes safety risk, low salaries, sexual

\footnotetext{
${ }^{1}$ The garments industry accounts for 78 per cent of the total exports and contributes 17 per cent of the GDP: Md Mahbub Alam Prodip and Fatema Ferdausi, 'How are Women Workers in RMG Sector?' The Financial Express, Dhaka (22 June 2014), Editorial.

2 Palash Ghosh, 'Despite Low Pay, Poor Work Conditions, Garment Factories Empowering Millions of Bangladeshi Women' International Business Time (25 March 2014), Politics.

3 Jubair Hasan, 'Unrest Feared if RMG Workers Not Paid $-\$ 150 \mathrm{~m}$ Needed in 18 Months for Factory Safety: Alliance' The Financial Express, Dhaka (26 July 2014), Last page.

4 Abdullah Shibli, 'Harvard Conference on Bangladesh- Whither Bangladesh Garments Industry?' The Daily Star, Dhaka (16 July 2014), Op-Ed.

${ }^{5}$ Palash Ghosh, above $\mathrm{n} 2$.

${ }^{6}$ Staff Correspondent, 'Unemployment the Biggest Challenge -Youths Can be Turned into Assets if Properly Trained' The Daily Star, Dhaka (11 July 2014), Frontpage.
} 
harassment, and both physical and verbal abuse. ${ }^{7}$ Employers ignore the safety requirements assumingly with a belief that the law is confined to the books and people are willing to work regardless of safety hazards. As a result, the number of workplace deaths and injuries continues to grow day by day with virtual impunity being granted to the wrongdoers leaving no redress for their victims. ${ }^{8}$ The unprecedented fire at Tazreen Fashions Ltd in November 2012 and the horrific collapse of Rana Plaza in April 2013 that claimed more than a thousand lives and caused serious injuries to many others have galvanised the agonies of garment workers in Bangladesh as discussed in Section D below. According to the US Committee on Foreign Relations, '[w] hen the Tazreen Fashions factory burned down, it was the worst garment factory accident in Bangladesh's history. When Rana Plaza collapsed, it was the worst garment factory accident in world history. ${ }^{9}$ The Committee adds that 'Bangladesh's garment sector may not be able to withstand another tragedy on the scale of Tazreen and Rana Plaza.' 10

Despite it being a valuable sector of the national economy, the garment industry until recently received little attention from both the Government of Bangladesh (GOB) as well as the profit-hungry importers of the developed world, who play on 'cheap labour, low production costs and a huge eager workforce'. ${ }^{11}$

An organised religion plays a pivotal role in developing personal values and human behaviour, thus it impacts on different aspects of businesses that are run by people who are generally faithful to a religious belief and practice. ${ }^{12}$ Islam is probably the single religion which is declared and acclaimed to be not merely a way of worship for the life hereafter, but a complete code of life encompassing 'an entire legal, economic, social, political, and commercial system' for its believers called Muslims. ${ }^{13}$

\footnotetext{
${ }^{7}$ Prodip and Ferdausi (2014), above n 1.

${ }^{8}$ The incidents and fatalities are discussed in Section D in this chapter.

${ }^{9}$ Committee on Foreign Relations - United States Senate, 'Worker Safety and Labor Rights in Bangladesh's Garment Sector (22 November 2013), 5.

${ }^{10} \mathrm{Id}, 13$.

${ }^{11}$ Ghosh (2014) above $\mathrm{n} 2$.

${ }^{12}$ See Geoffrey Williams and John Zinkin, 'Islam and CSR: A Study of the Compatibility between the Tenets of Islam and the UN Global Compact' (209) 91 Journal of Business Ethics 519, 519.

${ }^{13}$ See J. Michael Taylor, 'Islamic Banking- the Feasibility of Establishing an Islamic Bank in the United States' (2003) 40 American Business Law Journal 385, 387; Bernard K. Freamon, 'Slavery, Freedom, and the Doctrine of Consensus in Islamic Jurisprudence' (1998) 11 Harvard Human Rights Journal 1, 3 as cited in Radwa S. Elsaman, 'Corporate Social Responsibility in Islamic Law: Labor and Employment' (2011) 2 Yonsei Law Journal 64, 66.
} 
As regards the legal system, Bangladesh in practice belongs to the common law family as a former British colony and presently over $88 \%$ of its populace are Muslim. ${ }^{14}$ The labour law currently in force in the country was enacted in 2006 and amended in 2013 after the aforementioned destructions following enormous pressures from the developed nations and international bodies including the United Nations Organisation (UNO) and International Labour Organisation (ILO). Nevertheless, the labour law still remains flawed, which has been analysed elsewhere. ${ }^{15}$ This chapter is concerned with the right of workers to have a safe workplace and corresponding duties of their employers prescribed in the Islamic Law (Shari'ah). ${ }^{16}$ The objective of this writing is to show that the provisions of Shari'ah correspond to the labour rights as recognised in the prevailing law of the western world that are explicitly protective of workers' safety. The owners of both Tazreen Fashions and Raza Plaza are Muslim, ${ }^{17}$ and most of the workers died and injured are supposedly Muslims as the country's demography implies. Therefore as a Muslim, both the employees and employers (owners of the factories) are subject to the Islamic dictates at least religiously and ethically, if not legally. This research thus endeavours to examine the safety right of the workers and corresponding obligation of their employers under the principles of Islamic law, and concludes that the latter evidently failed to comply with their religious obligations to protect the former in addition to their failure under the municipal law.

As the discussions progress, the following Section B demonstrates the justification for this research. Section $\mathrm{C}$ briefly explains the legal concept of corporations and the notion of their social responsibility as recognised in the Shari'ah. Section D discusses the concerns for workplace safety or occupational health and safety (OHS) focusing on the principles of Shari'ah, whilst Section E concludes this chapter.

In discussing the OHS under the principles of Shari'ah, brief references to the relevant provisions of the Universal Declaration of Human Rights 1948 (UDHR), the International Covenant on Civil and Political Rights 1966 (ICCPR), the International Covenant on Economic, Social and Cultural Rights 1966 (ICESCR), the Universal Islamic Declaration of Human Rights 1981 (UIDHR), and the Cairo Declaration of Human Rights in Islam 1999

\footnotetext{
14 Board of Investment Bangladesh-Prime Minister's Office, 'Introduction' < http://www.boi.gov.bd/index.php/about-bangladesh/bangladesh-at-a-glance> (accessed on 23 July 2014).

${ }^{15}$ See S M Solaiman, 'Unprecedented Factory Fires of Tazreen Fashions in Bangladesh: Revisiting Bangladeshi Labour Laws in Light of Their Equivalents in Australia' (2013) 31(1) Hofstra Labor \& Employment Law Journal 125.

${ }^{16}$ Two terms, 'Islamic law' and 'Shari'ah', are used interchangeably in this chapter.

${ }^{17}$ They are respectively Mr Delwar Hossain and Mr Shohel Rana.
} 
(CDHR) will be made in order to demonstrate the inherent strength of Islamic principles which have come into being much earlier than the man-made instruments for protecting workers.

\section{Justification for This Research}

Although the Shari'ah is not part of the domestic or positive law of Bangladesh governing employment relationships, ${ }^{18}$ a vast majority of its people respect and voluntarily adhere to the rights and obligations enunciated in Islam concerning various aspects of Muslims, for example, marriage, divorce, inheritance, will of property, etc. Hence, an adequate understanding of rights and obligations under the Shari'ah would likely to stimulate both sides of the employment relation to be respectful towards each other's entitlements and duties. In addition, the justification for this pursuit lies in the fact that the business markets made up of Muslims around the world is significant, which warrants an understanding of corporate social responsibility (CSR) in the Islamic Legal System by both corporations and their stakeholders including employees. Notably, several recent studies demonstrate that some Muslim countries (countries having the majority of their population Muslim) are presently amongst the most wealthy market contributors in the global trade and commerce, such as, Saudi Arabia, Turkey and United Arab Emirates. ${ }^{19}$ Moreover, the large Muslim populace invite and expect multinational corporations to come into their markets as producers, manufacturers and investors. ${ }^{20}$ In response to this reality, several international law firms are now considering an expansion of their professional services to many Muslim countries, for example, Ashurst, a leading law firm, has extended its service network to many countries including United Arab Emirates, Indonesia and Saudi Arabia. ${ }^{21}$ More vividly, the intergovernmental Organisation of Islamic Cooperation (OIC) itself has 56 member countries, which have the majority of their population Muslim. Therefore, CSR in Islam has become a vital area of investigation by both academics and professionals. This chapter contributes to such an academic expedition.

\section{Corporations and Corporate Social Responsibility}

\footnotetext{
${ }^{18}$ In Bangladesh, the Shari'ah governs certain social and legal relations between Muslims such as marriage, divorce, inheritance, will of property etc, but not the relationship between an employer and an employee.

${ }^{19}$ For details, see Radwa S Elsaman, 'Corporate Social Responsibility in Islamic Law: Labor and Employment' (2012) 18 New England Journal of International and Comparative Law 97, 98.

20 John H. Donboli and Farnaz Kashefi, 'Doing Business in the Middle East: A Primer for U.S. Companies'(2005) 38 Cornell International Law Journal 413, 414.

${ }^{21}$ Ashurst, Locations http://www.ashurst.com/office.aspx?id_Content=14 (accessed on 12 July 2014).
} 
Everyone in the world is affected by corporations in one way or another simply because of the fact that the products we consume and services to use are provided by businesses formed predominantly as a company or corporation (these two terms used interchangeably). Today it would be unrealistic, if not impossible, for a person of any standing anywhere on earth to avoid corporation in his or her pursuit of living as a human being. A corporation is legally defined as an entity created by law conferring artificial personality ${ }^{22}$ as a veil of individuals who own and operate it for profits or other purposes with perpetuity in its existence and simplicity in its contractual relations. Initially, companies emerged as a division of society and gradually changed to an association of individuals. ${ }^{23}$ However, presently a single person can form a company. ${ }^{24}$

A corporation as a legal person does have both rights and responsibilities that are conferred and imposed on it with the recognition of a separate entity independent of its owners and managers. One of these obligations is social responsibility owed to the society in which it operates and thereby provides its products and services to the people for consumption. The notion of CSR is founded on the stakeholder theory of the corporation ${ }^{25}$ as opposed to the apparently rival stockholder theory of the corporation, ${ }^{26}$ whilst the former advances relatively new concepts compared to the latter which is solely devoted to the maximization of shareholders' benefits. ${ }^{27}$ A contemporary corporation in general has various responsibilities, such as financial, environmental and social. All these responsibilities have had a legal dimension which may vary between jurisdictions and legal systems. Therefore a single definition of any of these responsibilities is hard to be articulated.

In an effort to define CSR, some commentators argue that it 'is inherently vague and ambiguous, both in theory and practice'. ${ }^{28}$ In the absence of any universally accepted definition of CSR and recognition of the fact that any appropriate connotation of this concept

\footnotetext{
22 Salomon v Salomon \& Co Ltd [1897] AC 22.

${ }^{23}$ John P Davis, Corporations: A Study of the Origin and Development of Great Business Combinations and of Their Relation to the Authority of the State (1909) New York: B Franklin, 246.

${ }^{24}$ For example, in Australia, s113 of the Corporations Act 2001 (Cth) and s123 of the Companies Act 2006 (UK) allow formation of one member companies.

${ }^{25}$ See Jill Solomon and Aris Solomon, Corporate Governance and Accountability (2004) John Wiley \& Sons: West Sussex, 23-9.

${ }^{26}$ See Steen Thomsen and Martin Conyon, Corporate Governance: Mechanisms and Systems (2012) Berkshire: McGraw- Hill, 111-12.

${ }^{27}$ For a discussion of these two competing theories, see Thomas Donaldson and Lee E Preston, 'The Stakeholder Theory of the Corporation: Concepts, Evidence, and Implications' (1995) 20 (1) Academy of Management Review, 65-91.

${ }^{28}$ P R P Coelho, J E McClure, and J A Spry, The Social Responsibility of Corporate Management: A Classical Critique' (2003) 18(1) Mid-American Journal of Business 15, 15.
} 
(CRS) is problematic, ${ }^{29}$ it can be broadly described as being the responsibility to promote good and prevent harms of the society of consumers of products and services of a given corporation. ${ }^{30}$ The World Business Council for Sustainable Development defines CSR as 'the continuing commitment by business to behave ethically and contribute to economic development while improving the quality of life of the workforce and their families as well as of the local community and society at large'. ${ }^{31}$ The World Business Council further states that CSR refers largely to corporate ethical behavior towards society that particularly requires corporate management to act responsibly in its relationships with stakeholders who have legitimate interests in its business going beyond the interests of stockholders. ${ }^{32}$ Amongst the stakeholders, it goes beyond saying that that employees hold a significant stake in their corporation in terms of generating benefit for, and causing harm to, the respective society.

Islam is a religion of peace, harmony, brotherhood and tolerance. The Islamic principles consider business organisations and their responsibilities in a somewhat different way. This is because Islamic scholars in general firmly believe that the holy book of Qur'an is not merely a religious book, but a complete code of life as mentioned earlier. Hence the religious faith and conviction of Muslims considerably influence their everyday decisions including those of business transactions. ${ }^{33}$ CSR is integral to the concept of corporate governance. There are as good as six approaches to corporate governance recognised around the globe, an Islamic approach is one of them. ${ }^{34}$ As explained by the scholars of Shari'ah, the primary objective of corporate governance in Islam is ensuring 'fairness to all stakeholders to be attained through greater transparency and accountability. ${ }^{35}$ Kay and Silbertson term a large public corporation as a social organisation, and therefore should be governed by 'the concept of trusteeship' to sustain its assets' including 'the skills of its employees, the

\footnotetext{
${ }^{29}$ See Mark S Schwartz, Corporate Social Responsibility: An Ethical Approach (2011) Canada: Broadview Press, 15-17.

${ }^{30}$ Milton Friedman has given a completely different definition of CSR which is concerned solely with the protection of investor interests: see Milton Friedman, Capitalism and Freedom (1962) Chicago: University Press, 133.

${ }^{31}$ World Business Council for Sustainable Development, Meeting Changing Expectations: Corporate Social Responsibility (2000) 3 .

32 Ibid.

${ }^{33}$ Nisrine Abiad, Sharia, Muslim States and International Human Rights Treaty Obligations: A Comparative Study (2008) London: British Institute of International and Comparative Law (BIICL), 46.

34 Lewis (1999) identifies six models of corporate governance that include the Anglo-Saxon model, the Germanic model, the Japanese model, the Latinic model, the Confucian model and the Islamic model: M K Lewis, 'Corporate Governance and Corporate Financing in Different Cultures' as cited in Mervyn K Lewis, Islamic Corporate Governance' (2005) 9(1) Review of Islamic Economics 5, 23-24.

${ }^{35}$ See generally M Umer Chapra and Habib Admad, Corporate Governance in Islamic Financial Institutions (IRTI Publication Management System, Jeddah http://www.irtipms.org/PubDetE.asp?pub=93 (accessed on 1 August 2014).
} 
expectations of customers and suppliers, and the company's reputation in the community' would appear to sit comfortably with the Islamic thoughts of corporate governance. ${ }^{36}$ In this description of CSR, the skills of employees and corporate reputation in the community do inherently embrace the safety of workers at the workplace, the absence of which must negatively affect both employees' performance and corporate social image.

Further, the Islamic law puts the foremost emphasis on the structure of a commercial transaction in order to determine the presence of any element that may invalidate the profit stemmed from a business deal, and this structural investigation is somewhat similar to that of the secular corporate law which aims to strictly comply with the corporate charter. ${ }^{37}$ Any vitiating elements repugnant to the principles of Shari'ah in a transaction would render it illegal ipso facto. ${ }^{38}$ This is so because, Islamic corporate governance is concerned with both the substance as well as the form of the business transaction. ${ }^{39}$ When it comes to an employment relationship, the Shari'ah requires both the employers and their employees to adhere to the rights and obligations enshrined in the Islamic rules prescribed for maintaining a healthy relation between these two unequal parties with the spirit of brotherhood and harmony. Central to this relationship is the protection of employees at the workplace by their employers. Making money showing disregard for the relevant Islamic dictates should be religiously vitiated, therefore, would be regarded as prohibited for a Muslim employer. The Shari'ah contains specific principles for workplace safety that are binding on all Muslims at work.

\section{Occupational Health and Safety}

There is little dispute that life is more important than anything else, whilst any occupation is taken up by a person to live his/her life as a human being. However, the garment factories, especially their owners, seem to believe in the opposite, ie, a worker's life has been created for work regardless of the working environment, times and wages. This is so because, several thousand workers have died at their workplace in Bangladesh over the past

\footnotetext{
${ }^{36}$ J Kay and A Silbertson, 'Corporate Governance', (August 1995) National Institute Economic Review 90-91 as cited in Lewis (2005) above $\mathrm{n} 34,24$

${ }^{37}$ Ali A Ibrahim, 'Convergence of Corporate Governance and Islamic Financial Services Industry:

Toward Islamic Financial Services Securities Market' (2006) Georgetown University Law Center http://scholarship.law.georgetown.edu/gps_papers/3> 10 (accessed on 27 July 2014).

${ }^{38} \mathrm{Ibid}$

${ }^{39}$ See generally, Mahmoud A. El-Gamal, Islamic Finance: Law Economics and Practice (2006) as cited in Ibrahim (2006) above n 37.
} 
decade, but none has been punished for such irreparable losses to date. ${ }^{40}$ Despite the enormous significance of the garment sector for the national economy of Bangladesh, the incidents of deaths and fatal injuries used to fall on deaf ears until the collapse of an eightstorey building Rana Plaza in April 2013 which housed five garment factories. The Rana Plaza itself has killed at least 1,142 garment workers and seriously injured more than 2000 others, whilst 160 workers remain missing even after a year of the debacle. ${ }^{41}$ It unearthed the infinite miseries of millions of workers and reckless hunger of profits of the traders. The magnitude of the tragedy "not only shocks the conscience of humankind throughout the world, but also solicits our attention, assaults our moral propriety, and offends our sense of justice'. ${ }^{42}$

To make the situation even worse, fires at garment factories have become almost a normal phenomenon, whilst collapse of the factory buildings occurred several times in the past. Recurrent factory fires have been causing garment workers' deaths for decades without any legal recourse being available to them. The devastating fire at Tazreen Fashions Ltd in November 2012 alone burnt down 130 workers when its nine-storey factory building caught fire originating from an unauthorised cotton store room on the ground floor. ${ }^{43}$ It is obviously shocking, but none might look up in surprise in the country, because the Washington-based International Labour Rights Forum (ILRF) found at least 1,000 workers had been killed, while 3,000 others were injured in more than 275 incidents in garment factories alone in Bangladesh between 1990 and 2012. ${ }^{44}$

The devastations caused by both the breakdown of Rana Plaza and burning down of Tazreen Fashions warrant condemnation in the strongest possible terms. This is because, there were reportedly several warnings from respective authorities of the vulnerability of Rana Plaza preceding the collapse, ${ }^{45}$ nonetheless, the owner of the building and the

\footnotetext{
${ }^{40}$ Golam Mortuza, Pranab Bal and Mithhun Chowdhury, 'So Many Loss of Lives- but No One Punished' The Prothom Alo, Dhaka (1 Dec 2012), First page (translated from Bengali).

${ }^{41}$ Monira Munni, 'Rana Plaza Tragedy - BGMEA List Set to Put Missing 160' The Financial Express, Dhaka (13 July 2014), Last page; 'Rana Plaza Collapse - Primark Begins Paying Compensation' The Daily Star, Dhaka (8 June 2013), Front page; Hasnat Abdul Hye, 'The Stakeholders in RMG' The Financial Express, Dhaka (21 May 2013), Editorial; 'Two Accused in Rana Plaza Cases Get Bail' The Daily Star (28 January 2014), Business.

${ }^{42}$ M Rafiqul Islam, 'Savar Tragedy through Legal Prisms - Corporate Greed and Government Inaction' The Daily Star, Dhaka (11 May 2013), Law \& Our Rights.

${ }^{43}$ Nizam Ahmed, 'Improving Safety in BD RMG Sector - US Labour Department Announces \$2.5m Grant' The Financial Express, Dhaka (15 June 2013), Last page citing the US Labour Department.

${ }^{44}$ 'EU Worried - Nationwide Factory Inspection Begins' The Daily Star (31 January 2013) Dhaka, Front page.

${ }^{45}$ Zaglul Ahmed Chowdhury, News Analysis - Savar Tragedy: Garment Industry Must be Saved, Phasing Out the Errants, The Financial Express, Dhaka (5 May 2013), First page; '45 More Bodies Found, Death Toll Now
} 
proprietors of factories housed therein compelled the workers to come in and continue their work. Similarly, the middle managers of Tazreen, acting with gross negligence at its best and with reckless culpability at its worst, prevented workers from exiting the building even through the normal doors after it caught the fire, whilst the building did not have any emergency exits which are strictly required by the country's labour law. In addition, the Tazreen building had several deficiencies in respect of workplace safety. ${ }^{46}$ Paradoxically, the owner of Tazreen in his initial reaction after the fire expressed his deep concerns about losing business with overseas buyers instead of showing repentance for his workers' loss of invaluable lives. ${ }^{47}$ However, he subsequently claimed that no one had told him about the requirement of emergency exits which could have been otherwise easily included in the building. ${ }^{48}$

The international community for the first time woke up following such colossal losses of human lives which are virtually survived by the indefinable miseries of their hapless families. The International Labour Organisation (ILO) urged the Government of Bangladesh to take appropriate measures to ensure safety of workers and to prevent the recurrence of such 'entirely avoidable workplace tragedies'. ${ }^{49}$ The incidents also moved the SecretaryGeneral of the United Nations who expressed his deep sorrow for those deaths, whilst the European Mission visiting Bangladesh to see the devastation themselves also joined others in expressing their shocks. ${ }^{50}$ The United States, a vital customer of garment products, in its response to the catastrophes asked the government to improve safety conditions at the workplace and took a punitive measure by suspending Bangladesh from the Generalised System of Preferences (GSP) program which has not been restored to date despite repeated requests of government. ${ }^{51}$ The continued refusals of the United States to restore the

550' The Financial Express, Dhaka (5 May 2013), First page; '38 More Bodies Recovered, Toll 425 - 32 Unclaimed Bodies Buried at Jurain after DNA Test' The Financial Express, Dhaka (3 May 2013), First page; Inam Ahmed '9-Storey Building Caves in - Rescue Races against Time' The Daily Star, Dhaka (25 April 2013) ,Front page; Nizam Ahmed, 'Savar Tragedy Triggers Outcry Worldwide -RMG Exports Likely to be Affected' The Financial Express, Dhaka (26 April 2013), First page.

${ }^{46}$ See, for details, Solaiman (2013), above n 15.

${ }^{47}$ M Shahidul Islam, 'Conspiracy Theory Laks Credibility - Deadly Garment Fire Shakes Buyers' Confidence' The Weekly Holiday, Dhaka (30 Nov 2012), Front page.

48 Refayet Ullah Mirdha \& Sarwar A Chowdhury, 'My Fault, but None Alerted Me - Tazreen MD Tells Star' The Daily Star, Dhaka (29 Nov 2012), Front page.

49 'ILO for Quick Action: Ensure Safety to Garment Workers', The New Nation, Dhaka (5 May 2013).

${ }^{50}$ Nizam Ahmed, 'UN Chief Condoles Deaths in Savar Bldg Collapse, The Financial Express, Dhaka (28 April 2013).

${ }^{51}$ Wasi Ahmed, 'US GSP Suspension and the Worry-Box' The Financial Express, Dhaka (30 June 2013), Editorial; Rahman Jahangir, 'RMG: Roadblocks versus Roadmap' The Financial Express, Dhaka (12 July 2014), Editorial. 
suspended GSP conform to the reports of the British weekly newspaper, The Economist, that no serious effort to improve workplace environment have been taken to bring the safety standard acceptable to the international community. ${ }^{52}$ These clearly indicate that the international pressures against the government and factory owners are mounting, and the US Senate Committee prescribes that the 'surest way to guarantee the success of the apparel industry is to avoid another disaster by promoting and protecting labor rights now, while the world's attention is on Bangladesh. The present opportunity to improve working conditions in Bangladesh cannot be squandered.' 53

The Islamic law regarding corporations sharply contrasts to the 'self-interested agents' model of corporate governance, which is considered to be the most extreme view operating in the 'ruthless economy' with a 'cowered labour force' as Samuelson coins it. ${ }^{54}$ This model emphasises maximisation of shareholder value where the market force disciplines and controls the economic actors in a free market economy. ${ }^{55}$ The Islamic model rests on largely the stakeholder model of corporate regulation. The Shari'ah encourages production of essentials for humans whilst imposes prohibition on financing goods and services that are in conflict with the Islamic values and principles (haram activities), such as, producing alcohol, facilitating gambling (maysir), engaging in usury (riba) and stimulating uncertainty (gharar). ${ }^{56}$ Further, the Islamic law also fosters the protection of environment, vegetation and even animals. ${ }^{57}$ It would be imprudent to argue that such prohibitions have been put in place for nothing. This is so because, all the prohibited things in business have negative impacts on human health and life. ${ }^{58}$ The Qur'an itself explains the justification for such prohibitions while it provides that: 'In them is great sin, and some benefit for people; but the sin is greater than their benefit'. ${ }^{59}$ The concern of this chapter goes far beyond any ordinary harm of humans because it relates to human life and safety.

\footnotetext{
${ }^{52}$ See 'No Serious Efforts to Improve Factory Safety- The Economist Focuses on Rift among Retailers', The Financial Express, Dhaka (13 July 2013), Last page.

${ }^{53}$ Committee on Foreign Relations (2013) above n 9, 13.

${ }^{54}$ P Samuelson, 'Where do the European and American Models Differ' as cited in Lewis (2005) above n $34,23$.

${ }^{55}$ Lewis (2005) above n 34, 23.

56 Ibid.

${ }^{57}$ Ibid.

${ }^{58}$ See Williams \& Zinkin (2010), 'Islam and CSR: A Study of the Compatibility between the Tenets of Islam and the UN Global Compact' (2010)91 Journal of Business Ethics 519, 523.

${ }^{59}$ The Holy Qur'an, Chapter 2 Verse 219. checked
} 
The right to life is a universally recognised human right. In addition, it is a fundamental right in Bangladesh as enshrined in its Constitution. ${ }^{60}$ The Supreme Court of Bangladesh has pronounced on several occasions that the state has binding obligations to protect fundamental rights. For example, the Supreme Court in Ain O Salish Kendra (ASK) v Government of Bangladesh held that the state is constitutionally obligated to make effective provisions for securing the right to life, living and livelihood within its economic capacity. ${ }^{61}$ Consistently, the Shari'ah provides explicit provisions for the protection of life and security of human being without any discrimination being made based on any consideration as the Holy Qur'an ordains that 'Take not life, which Allah has made sacred except through justice and law. ${ }^{92}$ The importance of life given by the divine book is further evident in its words equating one life with that of the mankind, 'that if anyone slew a person unless it be for murder or for the spreading of mischief in the land - it would be as if he slew the whole people, and if anyone saved a life, it would be as if he had saved the life of the whole people. ${ }^{63}$ Obviously, this prohibition applies to everyone without any discrimination against anyone and does 'make it clear that Muslims are obliged to protect life wherever possible, as well as to be careful about how a life should be taken. ${ }^{64}$

The Shari'ah is always in favour of discipline and adherence to the religious norms in every sphere of human life, thus it gives importance to justice and equality of treatment at work, and does permit hierarchies in corporate management. The Islamic law believes in 'freedom, justice and equality' and opposes 'discretion, injustice and inequality in the workplace'. ${ }^{65}$ Islam, as a religion, provides guarantee for workplace safety. ${ }^{66}$ The Shari'ah provides the details of entitlements of employees and their employers that can 'neither be abrogated nor be disregarded'. ${ }^{67}$ Regarding workplace in particular, the Qur'an mentions '...He has raised you in ranks, some above others: that He may try you in that which He has bestowed on you'. ${ }^{68}$ So, a clear emphasis on the greater responsibility of a higher position at work is evident in this Qur'anic verse. Labour is well regarded as being dignified human

\footnotetext{
${ }^{60}$ Art 32 of the Constitution of Bangladesh.

61 (1999) 19 BLD (HCD) 488.

62 The Holy Qur'an, Chapter 6, Verse 151. checked

${ }^{63}$ The Holy Qur'an Chapter 5, Verse 32. checked

${ }^{64}$ Williams \& Zinkin (2009) above n 12, 525.

${ }^{65}$ Rozanah Ab Rahman, 'Protection of Safety, Health and Welfare of Employees at Workplace under Islamic Law' (2006) 14(1) IIUM Law Journal 51, 51.

${ }^{66} \mathrm{Id}, 53$.

${ }^{67}$ Id, 52.

${ }^{68}$ The Holy Qur'an, Chapter 6, Verse 165. Checked
} 
contribution to, or factor of, production in Islam and employment obligations must be properly discharged based on contracts that mirror justice on the part of both employers and their employees. ${ }^{69}$ The prohibition on the oppressive conduct of higher officials with their subordinate colleagues is further evidenced by the words of Prophet Mohammed (SM) who asked people to 'help their brothers whether he is the oppressor or the oppressed, i.e. if one is an oppressor another should prevent him from doing it, for that is his help and if one is the oppressed he should be helped (against oppression). ${ }^{70}$ Allah has categorically made oppression against one another unlawful. ${ }^{71}$

Regarding compelling a worker to do certain job, the Qur'an pronounces that 'on no soul doth Allah place a burden greater than it can bear'. ${ }^{72}$ Also, workplace safety is required by the Qur'an itself which orders that '... make not your hands contribute to your (own) destruction (by refraining); and do good; indeed, Allah loves the doers of good. ${ }^{73}$ The Qur'an further says that 'You are the best community which has been brought forth for mankind. You command what is right and forbid what is wrong and you believe in Allah' ${ }^{74}$ These Qur'anic orders are reinforced by the words of Prophet Mohammed (SM) who said that 'Do not ask them to do any job that is beyond their abilities and if you have to, then you must help them fulfilling such a work. ${ }^{, 75} \mathrm{He}$ has further advised employers to ensure fair labour practices that:

Your employees are your brethren upon whom Allah has given you authority. Hence, if one has one's brother under his/her control, one should feed them with the like of what one eats and clothe them with the like of what one wears. Even no workers can be compelled to do more than what they are capable of doing, and the employer is obligated to provide safe workplace. You should not overburden them with what they cannot bear, and if you do so, help them in their job. ${ }^{76}$

Hence, Islamic law requires employers to provide acceptable working conditions to their workers and give them only reasonable kinds of work. ${ }^{77}$ All employees must be treated

\footnotetext{
${ }^{69}$ Rahman (2006), above n 65, 52.

${ }^{70}$ Shahi Muslim, Book 3, Hadith No. 6246.

${ }^{71}$ Sahih Muslim, Book 3 Hadith No. 6254.

72 The Qur'an, Chapter 2, Verse 286. checked

73 The Qur'an, Chapter 2, Verse 195. Checked

74 The Qur'an, Chapter 3, Verse 110. checked

${ }^{75}$ Muhammad Muhsin Khan, Sah-ih al-Bukh-ar-i (Dar Al Arabia, 4th ed., 1994), 18.

${ }^{76}$ Sahih al Muslim Book 3: Hadith No. 4093. See also Elsaman (2012) above n 19, 112.

77 Beekun \& Gamal A. Badawi, 'Balancing Ethical Responsibility Among Multiple Organizational Stakeholders: The Islamic Perspective', (2005) 60 Journal of Business Ethics 131, 138.
} 
fairly and equitably and no discrimination is permitted in Islam. The Prophet enunciates in his last sermon reinforcing the people's right to be treated equally as Allah has assured everyone's enjoyment of bounties on earth that:

'No Arab has superiority over any non-Arab and no non-Arab has any superiority over an Arab; no dark person has superiority over a white person and no white person has any superiority over a dark person. The criterion of honour in the sight of Allah is righteousness and honest living. ${ }^{, 78}$

The foregoing discussion demonstrates that the treatment of Islam with workers is well protective of their safety, cooperative and healthy workplace. Prohibitions against forced labour and negligence about safe working environment are categorical and unambiguous. The principles of Shari'ah are in full alignment with the prevailing western law as well as the standards set forth by the international community. The Shari'ah seems to be one step ahead of the man-made law in that no other laws explicitly require an employer to be so kind and generous towards his/her employees. This is because the Shari'ah requires employers to feed their employees with the foods they eat, and to provide them with the clothes that they wear as alluded to above. This is certainly distinctive from the conventional laws. This underscores the central thirst of brotherhood and equality in Islam, which disapproves any lack of safety at the workplace and prohibits any prejudicial or deleterious behaviour of the employer with their employees.

Thee Shari'ah principles are applicable to the negligent or reckless conduct of garment factories with their workers. The employers or owners of the garment factories should adhere to these Islamic principles as long as they believe in Islam apart from the potential sanctions against the breach of the pertinent municipal law. But in practice, their conduct directly contradicts the Islamic principles. Tazreen mid managers reportedly compelled factory workers to stay at work despite fires, whilst its owner ignored the responsibility to ensure safe working environment for his workers. On the other hand, the owner of Rana Plaza along with the proprietors of the factories established therein allegedly forced the ill-fated workers to come to work despite the repeated public warnings of life-risk of the occupants. ${ }^{79}$ These directly breach the principles of Shari'ah which impose liability directly on individuals as it does not recognise corporate separate personality unlike the man-

\footnotetext{
${ }^{78}$ The Prophet's Last Sermon, delivered on the Ninth day of Dhul al Hijjah 10 A.H. in the 'Uranah valley of Mount Arafat in 632 A.C.

${ }^{79}$ See the sources cited in above $\mathrm{n} 45$.
} 
made law. Therefore the owners and executives, instead of their corporations, bear the liability for the casualties mentioned earlier. ${ }^{80}$ This individual-centric responsibility denotes a significant difference between the concepts of corporate personality under the conventional law and the Shari'ah in that 'the corporation is no more than a legal entity that has no responsibilities that can be separated from those of the individuals who make up the organisation' in Islam. ${ }^{81}$ Hence owners or employers and their executives have the primary liability for any lack of safety measures at the workplace.

Along the line of Shari'ah, the formulation and operation of several major international efforts to protect human life and workplace safety can be found. The first global instrument on people's rights is the Universal Declaration of Human Rights 1948 (UDHR). Its Art 3 pronounces that 'Everyone has the right to life, liberty and security of person', whilst it begins with Art 1 by reassuring that 'All human beings are born free and equal in dignity and rights. They are endowed with reason and conscience and should act tow ards one another in a spirit of brotherhood.' So, any negligence or recklessness in protecting workers' lives would breach this charter of the humankind.

Adding legal force to the UDHR the, Art 6(1) of the International Covenant on Civil and Political Rights 1966 as ratified by Bangladesh ${ }^{82}$ states that 'Every human being has the inherent right to life. This right shall be protected by law. No one shall be arbitrarily deprived of his life.' Likewise, the International Covenant on Economic, Social and Cultural Rights 1966 to which Bangladesh is a state party ${ }^{83}$ contains an explicit provision pertaining to workplace safety. Its Article 7 provides that 'The States Parties to the present Covenant recognize the right of everyone to the enjoyment of just and favourable conditions of work which ensure, in particular: ... (ii) A decent living for themselves and their families in accordance with the provisions of the present Covenant; (b) Safe and healthy working conditions....'

The Cairo Declaration of Human Rights in Islam 1999 articulated in light of the Islamic principles contains clear provisions concerning rights of workers. It incorporates,

\footnotetext{
${ }^{80}$ See A Bhatia, Speech given by Lord Bhatia entitled 'CSR: An Islamic Perspective' at a Conference on 'Singapore/UK Developing Corporate Social Responsibility' at the Shangri La hotel in Singapore on 23 February 2004 as cited in Williams \& Zinkin (2009), above n 12, 529. 81 Ibid.

${ }^{82}$ Bangladesh ratified the ICCPR on 05 October 1998.

${ }^{83}$ Bangladesh ratified the ICESCR on 07 September 2000.
} 
amongst others things, the right to work itself, the right to enjoy safety, security and social guarantee, the right not to be compelled to work beyond one's capacity, and the right not to be subject to any harm. These rights are enshrined in its Art 13 and 14. Article 13 reads: ${ }^{84}$

Work is a right guaranteed by the State and Society for each person able to work. Everyone shall be free to choose the work that suits him [or her] best and which serves his [or her] interests and those of society. The employee shall have the right to safety and security as well as to all other social guarantees. He [or she] may neither be assigned work beyond his capacity nor be subjected to compulsion or exploited or harmed in any way.

Article 14 adds 'Everyone shall have the right to legitimate gains without monopolization, deceit or harm to oneself or to others...'

Likewise, the Universal Islamic Declaration of Human Rights 1981 (UIDHR) having regard to the Qur'an and Sunnah categorically abhors slavery and forced labour. ${ }^{85}$

Therefore, the Islamic international documents are clearly in complete agreement with the international law on workplace safety.

\section{Conclusions}

Both international secular instruments and the principles of Islamic law strongly assert that maintenance of workplace safety is an essential obligation of employers. CSR does not uphold a concept of charity or philanthropy; rather it denotes the responsibility of corporations as an integral part of the national and international communities to protect those who may be affected by their (corporations) actions or omissions in both short and long terms. As a means of long term risk management, 'CSR recognises the importance of investing in man-made capital to make the workplace safer, and factories and infrastructure more productive'. ${ }^{86}$ It plays a positive role to improve financial

\footnotetext{
${ }^{84}$ The Cairo Declaration on Human Rights in Islam 1990, Arts. 13-14.

${ }^{85}$ Preamble g(iii) of the UIDHR.

${ }^{86}$ John Zinkin, 'Why Malaysia's Companies Should be Socially Responsible' Malaysian Business (1 August 2004) 56-57.
} 
performance, enhance brand name and reputation and increase the ability to attract, motivate and retain the best workforce. ${ }^{87}$

Garments owners in Bangladesh appear to be complacent by offering an earning opportunity to millions of unemployed poor youths especially untrained women without adequate safety standards and remuneration. Many workers too are thought to be seemingly happy with whatever they get in exchange for their hard labour believing in the old saying that 'something is better than nothing'. They fear that they may lose whatever they are presently earning, if they want more from their employers. Therefore, they have to continue to work with a calm disappointment for years. The discontent gets worse when it is amplified by safety concerns. Such a workplace environment is not only exploitive, but also unproductive simply because workers' motivation for work is affected by the feeling of unsafety and deprivation. The existence of such an atmosphere at the workplace is not only condemned, but proscribed in Islam. Hence both the owners and workers especially when they are Muslim need to be respectful to each other's rights and obligations for mutual interests in this life, as well as for the divine rewards in the eternal life hereafter under Islamic teachings. Employers, by virtue of their higher rank, do have a greater responsibility compared to that of their employees to ensure compliance with the Shari'ah principles.

The preceding discussions provide evidence of the fact that Islamic principles are by no means in conflict with the spirit of CSR currently prevailing throughout the globe especially in the developed world in the era of 'corporate tyranny'. Rather the Shari'ah is unambiguous in imposing responsibility on individuals in exclusion of the entity itself for ignoring workplace safety. ${ }^{88}$ Personal liability does work as incentives to comply with regulation which is attached to sanctions. ${ }^{89}$

In response to a potential question as to why the employers in Bangladesh should abide by the CSR principles of Shari'ah, John Zinkin's contention in a Malaysian context could be mentioned that 'it makes good business sense; it is the Islami

\footnotetext{
${ }^{87}$ Id, 56.

${ }^{88}$ See Williams \& Zinkin, (2009), above n 12, 520.

89 See F Gigler, 'Discussion of an Analysis of Auditor Liability Rules' (1994) 32 Journal of Accounting Research 61, 64, R Schwartz, 'Legal Regime, Audit Quality and Investment' (1997) 72 Accounting Review 385, 397-98.
} 
way of doing business; and it is good risk management.' 90 Bangladesh is clearly comparable with Malaysia in terms of both religion and business in general, although the former is much stronger than the latter particularly in the garment sector. Bangladesh cannot afford to lose the dominating position of its garment industry in home and abroad in the interest of economic and social wellbeing of the nation at the very least. Moreover, Islam is a religion which contains the ultimate code of human life, it instructs employers to embrace their workers with due kindness, respect, honour and a sense of brotherhood. All these collectively obligate employers to provide a safe and healthy workplace for their workers.

\section{Short Bio of S M Solaiman}

Dr S M Solaiman is an Associate Professor of Law, University Wollongong, Australia. He has over 27 years of legal teaching and research experience at universities in Australia and overseas. He has published more than 50 journal articles and 2 book chapters. His articles have been widely cited in scholarly publications of 18 countries, mostly in the US, the UK, Australia and Europe. Solaiman has also presented 43 conference/seminar papers including invited keynote speeches and public lectures across continents. He had been a visiting scholar at different renowned universities in Europe, Australia, Asia and New Zealand. Solaiman's research interests include securities regulation law, corporations law, corporate criminal liability, Asian law, business law, criminal law and constitutional law. He has obtained a number of internal and external research grants for different projects. Solaiman has successfully supervised several $\mathrm{PhD}$ theses to completion. He can be reached at sheikh@uow.edu.au.

\footnotetext{
${ }^{90}$ Zinkin (2004), above n 86, 56.
} 